Goldschmidt 2021 Abstract

https://doi.org/10.7185/gold2021.6343

\section{Formation of Titanomagnetite Rims on Ferromagnesian Phenocrysts of Adakitic Rocks of the Torud-Ahmad Abad magmatic belt, Iran: examination of opacitization processes}

\section{FAZILAT YOUSEFI ${ }^{1}$ AND DAVID LENTZ ${ }^{2}$}

\author{
${ }^{1}$ University of New Brunswick (UNB) \\ ${ }^{2}$ University of New Brunswick \\ Presenting Author: fazilat.yousefi@unb.ca
}

Adakitic rocks in the magmatic belt of Torud Ahmadabad are located south-southeast of Shahrood (north of the Central Iran Zone). These adakitic rocks, in the form of dikes and other hypabyssal igneous rocks, were emplaced into late Neoproterozoic amphibolite and mylonitized granites and a thick sequence of Paleocene to middle Eocene volcanic and volcanosedimentary rocks. The composition of these adakitic rocks includes basaltic andesite, andesite, trachyandesite, dacite, trachydacite, and dacite; they are mainly composed of calcic pyroxene, $\mathrm{Ca}-\mathrm{Na}$ amphibole, and plagioclase phyric rocks, with minor biotite and titanomagnetite (Fig. 1). In the Torud Ahmadabad intrusions, iron-titanium oxides are observed mainly as late crystallizing or secondary phases [1]. These opacitized rims around these hornblendes are due to the reaction of the melt and volatiles. The intensity and color of these opacitized margins depend on the extent of titanomagnetite-magnetite formed. Using the $\mathrm{FeO}-\mathrm{Fe}_{2} \mathrm{O}_{3}-\mathrm{TiO}_{2}$ [2] ternary diagram, composition of titanomagnetite to magnetite was determined (Fig. 2). Magnetite and titanomagnetite are minor minerals in most samples. One of the interesting features of these rocks is the opacitization of ferromagnesian phenocrysts, such as hornblende. Thickness of these opaque rims varies [Fig. 1]. These reaction rims on hornblende are evidently due to an oxidative reaction with the melt during hypabyssal emplacement. The phenomenon of opacitization is due to decreasing stability of ferrous iron and hydrous ferromagnesian minerals, such as amphiboles, to less hydrous to anhydrous surface environment [3]. The rapid decrease in pressure during magma ascent causes hornblende instability and creates opaque margins (titanomagnetite partial replacement). Hornblende instability can generally be due to factors, such as melt degassing [decrease in $\mathrm{P}\left(\mathrm{H}_{2} \mathrm{O}\right)$ ] during the process of ascent and reduction of magmatic pressure, increasing the temperature, and (or) melt oxidation [4]. Bimetasomatic reaction between hornblende and melt produced the opacity (rims) that seems to be associated with the following zoning: hornblende $\rightarrow \mathrm{Px}+\mathrm{Plg}+\mathrm{Ti}-\mathrm{Mag} \rightarrow \mathrm{Px}+\mathrm{Plg} \rightarrow \mathrm{Px} \rightarrow$ melt [4]. The relative influence of various factors affecting the process of opacitization, oxidation of hornblende to form titanomagnetite, are examined. [1]Yousefi Y.F. (2017a), 1-15. [2]Carmichael I.S.E. (1976), 36-64. [3]Middlemost, E.A., 1986, 266p. [4] Plechov, P.Y. (2008), 19-35.

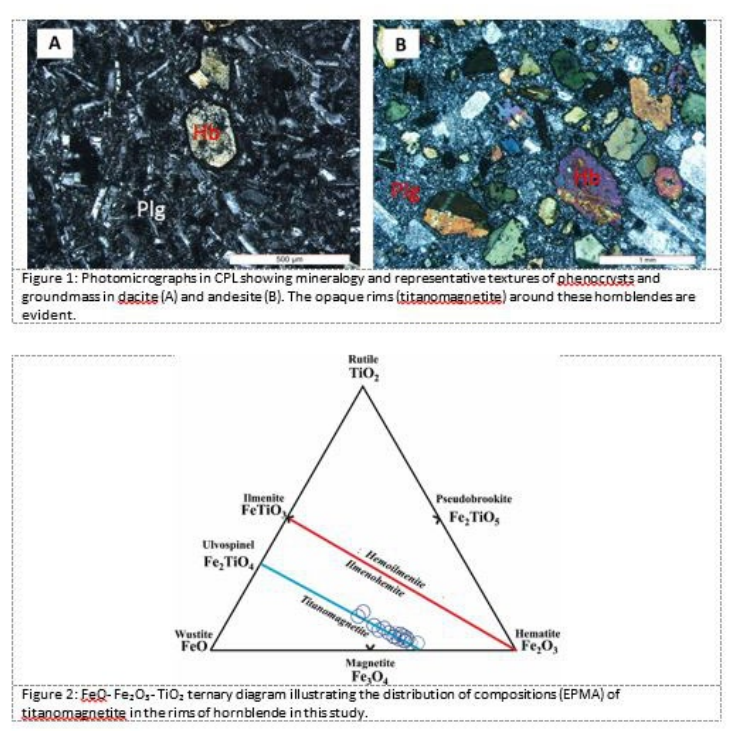

